\title{
Exchange rates and FDI strategies of multinational enterprises
}

\author{
Bong Soo Lee ${ }^{\mathrm{a}}$, Byung S. Min ${ }^{\mathrm{b}}$ \\ ${ }^{a}$ Department of Finance, College of Business, Florida State University, 311 Rovetta \\ Business Building, Tallahassee, FL 32306, U.S.A. (blee2@cob.fsu.edu) \\ ${ }^{\mathrm{b}}$ Griffith Business School, Department of International Business and Asian Studies, \\ Griffith University, Nathan Campus, Qld 4111, Australia (b.min@griffith.edu.au)
}

\begin{abstract}
We examine the role of both the volatility and levels of exchange rates in the determination of multinational enterprises' (MNEs) investments using a unique Korean dataset. These data provide a natural laboratory due to the Korean experience of a severe financial crisis in the late nineties. We find, first, that the behavior of foreign investors in Korea has changed following the 1997 crisis. The change in foreign direct investment (FDI) in response to exchange rate volatility is robust, while that to exchange rate level is quite mixed, which is consistent with recently developed real option-based FDI theory. Second, the effect of exchange rate volatility on FDI is persistent, whereas that of misalignment of level is only temporary, suggesting that MNEs regard volatility as a more generic determinant of foreign investment than misalignment of the exchange rate level. Third, we find strong evidence of nonlinearity between uncertainty and FDI, which may shed some light on why existing literature shows mixed results on the relation between exchange rate variables and FDI.
\end{abstract}

JEL classification:

$\mathrm{O} 53$

F21

F23

Keywords:

Exchange rate

Financial crisis

Foreign direct investment (FDI)

Multinational enterprises (MNEs)

South Korea 


\section{Introduction}

Prior studies have found that investments by multinational enterprises (MNEs) across international borders are affected by movements and volatility in exchange rates. However, the respective role of exchange rate levels and volatility in the determinations of foreign direct investment (FDI) has been debated in the literature. In this paper, we re-examine the role of exchange rate levels and volatility in the determination of FDI, using the data on FDI in South Korea (hereafter, Korea).

Korea experienced a severe financial crisis around 1997 as part of the Asian financial crisis which resulted in a substantial devaluation of its currency against major foreign currencies and a significant increase in its exchange rate volatility. Following recommendations of the IMF, Korea has switched to a floating exchange rate regime and eliminated most of foreign investment restrictions. After the crisis, the importance of FDI has increased remarkably. FDI inflows have increased from 997.7 million U.S. dollars (439.4 cases) per annum before the crisis (1981-1996) to 10.9 billion U.S. dollars (2,687 cases) per annum after the crisis (1997-2006). Namely, the share of FDI inflows in the GDP valued at 1998 prices increased from 0.3 percent before the crisis to 3.4 percent following the crisis. Given all these developments, the Korean experience provides a natural laboratory for the reexamination of the respective role of exchange rate volatility and levels in changes in FDI by comparing the relations before and after the financial crisis.

The existing studies on exchange rates and FDI mainly focus on investments by Japanese and U.S. MNEs in the U.S. and EU, using either level or volatility of exchange rates. However, theories and empirical studies on FDI have generated mixed support for a link between exchange rate movements and FDI (Blonigen 1997). Three seminal papers by Froot and Stein (1991), Kogut and Chang (1996) and Blonigen (1997) analyze Japanese FDI in the U.S. during the 1980s. Both Froot and Stein (1991) and Blonigen (1997) analyze the role of real exchange rates, the former using aggregate data, while the latter uses sectoral data. Kogut and Chang (1996) analyze Japanese electronic firms' investments in the U.S.

The estimation results by Caves (1989), Swenson (1994) and Klein and Rosengren (1994) support the proposition that FDI inflows are facilitated by depreciation of the currency of the host economy, whereas studies by Ray (1989) and 
Healy et al. (1993) fail to support this proposal. Cushman (1985, 1988), Goldberg et al. (1995) and Zhang (2004) support the theory that exchange rate volatility stimulates U.S. FDI abroad. By contrast, Galgau and Sekkat (2004) find that the volatility in EU exchange rates has a deterrent effect on FDI.

Existing studies on FDI in Korea focus on traditional determinants such as trade (Min, 2006; Lee, 1994) and wage-related labor strikes (Tcha, 1998). Aguiar and Gopinath (2005) and Pulvino (1998) analyze FDI inflows in selected Asian countries following the crisis but focus primarily on the effect of liquidity-induced sales on the number of acquisitions, without considering the exchange rate variables.

In contrast to prior studies, we focus on the effect of both exchange rate movements and volatility on FDI inflows from developed economies to a small open economy, paying special attention to the impact of the 1997 financial crisis and using extensive panel data analyses. Given mixed evidence in prior studies, we make efforts to find robust empirical evidence on the relation between FDI and exchange rate variables.

While the effect of exchange rate volatility on multinational enterprise's (MNEs) investment decision has been explored, this paper differs from existing studies in the following three perspectives. First, the exchange rate volatility we investigate in this paper is caused neither directly by policy shocks nor by de facto trade barriers. ${ }^{1}$ Most existing studies assume exchange rates are endogenous as a function of relative money supply between source and host countries (Aizenman, 1992; Devereur and Engel, 2001; Goldberg and Kolstad, 2005; Russ, 2007). This assumption allows researchers to take into account secondary effects including demand shocks caused by the change in money supply. In contrast, the shocks in this paper are largely from international investors' confidence around the regional financial crisis in Asia. Kawai (2000), among others, attributes the cause of the Asian financial crisis to rapid in- and out-flows of capital in the region. ${ }^{2}$ Consequently, our paper focuses on the first-order impacts rather than the secondary effect (i.e., consumer demand) and thus is relatively free from estimation bias associated with an endogenous variable.

Second, existing studies on the association between exchange rate and FDI are largely about the case of the U.S. Our paper examines the issue for a small open

\footnotetext{
${ }^{1}$ Refer to Mundell (1957), Goldberg and Kolstad (1995), and Cushman (1985) for the exchange rate volatility associated with de facto trade barriers.
} 
economy. Literature about FDI in emerging economies tends to focus on vertical integration based on the traditional ownership-location-internalization framework or the impact of FDI on the host economies (e.g., Braconier et al., 2005; Enlight, 2009; Aybar and Aysun, 2009).

Third, we investigate the effect of exchange rate volatility on MNEs' investment decision comparing between two sub-samples: before (or under fixed exchange rate system) and after the financial crisis (or under floating system). Given strong evidence of structural change around 1997, we employ two empirical models to address the structural change: a two-group model and a crisis dummy variable model. We use two types of measures for FDI: level of FDI and its ratio to GDP. For exchange rate volatility, we use both observed data (i.e., moving averaged standard deviation) and GARCH-based prediction.

We find that the behavior of foreign investors in Korea has changed following the 1997 crisis. Although exchange rate variables (i.e., both volatility and level) have a significant effect on FDI before the crisis, only the effect of exchange rate volatility remains robust. This is consistent with recently developed real option-based theory that MNEs would consider uncertainty-driven value of waiting in their decision-making process. Further, we find that the duration of the effect of exchange rate volatility and level on FDI is different in that the effect of exchange rate volatility on FDI is persistent, whereas that of misalignment of level is only temporary. In contrast with the existing literature we find strong evidence of nonlinearity in the relation between uncertainty and investment. This finding is consistent with the recent development of option-based investment theory and may shed some light on why existing literature shows mixed results on the relation between exchange rate variables and FDI.

The paper is organized as follows. In Section 2, we briefly review the literature with a view to formulating our empirical hypotheses. In Section 3, we present our empirical models that take into account potential structural changes: a two-group model and a crisis dummy variable model. In Section 4, we describe our data and their sources. In Section 5, we present and discuss empirical results. Our focus is on examining the robustness of our major findings. We conclude in Section 6.

\section{Empirical hypotheses}

\footnotetext{
${ }^{2}$ The V-shaped recovery of the economy's GDP growth also supports the argument that the 1997 crisis
} 


\subsection{Exchange rate volatility and FDI}

Theoretical predictions on the effects of exchange rate volatility on FDI flows are diverse. Dixit and Pindyck (1994, 1995), Pindyck (1998), Campa (1993) and Rivoli and Salorio (1996) claim that the changing value of real options, stemming from unexpected business uncertainty about the financial market, is the driving force behind FDI. One implication of this theory is that, given the sunk cost nature of local fixed costs, MNEs can withhold FDI if exchange rate uncertainty increases. Exchange rate volatility leads to uncertainty about the return, thereby increasing the value of delaying FDI. This option theory-based argument is valid even for risk neutral MNEs, as the sunk cost is the main determinant of the option value of holding investment.

By contrast, Devereux and Engel (2001) suggest that FDI can be better facilitated under a flexible exchange rate than under a fixed exchange rate, particularly when firms price their investments in the currency of the local market. ${ }^{3}$ This is consistent with the fact that floating regimes generally stimulate production by all firms, including the subsidiaries of MNEs. Itagaki (1980) shows that an increase in exchange rate volatility may motivate MNEs to invest abroad as a way of hedging (by the value of assets and repatriated profit streams from abroad) against a short position (value of domestic assets relative to foreign liabilities) on their balance sheets. Goldberg and Kolstad (1995) show that exchange rate volatility can increase the share of risk-averse MNEs' production capacity that is located abroad if production costs are positively correlated with revenues from these foreign markets.

On the other hand, Aizenman and Marion (2004) propose that the response of MNEs to exchange rate volatility would differ depending on real or nominal shocks, whereas Russ's (2007) general equilibrium model suggests that an MNE's response to volatility will differ depending on whether this volatility arises from shocks in the source country or the host country.

was largely exogenous to Korea.

${ }^{3}$ MNEs' investment decisions are based on their 'perceived' cash flows in their home currencies (i.e., source country's currencies) generated by foreign investments. However, the expression of bilateral exchange rate in empirical studies differs depending on authors. For example, Campa (1993) measured exchange rates using indirect quotation (i.e., quantity terms) to the investors whereas Goldberg and Kolstad (1995) used direct quoting (i.e., price quotation). We followed Goldberg et al. 
As discussed above, the predictions of the effect of exchange rate volatility on FDI differ depending on the hypotheses. The effect would be negative according to Dixit-Pindyck's option theory and/or Aizenman's (1992) inflexibility of production structure hypothesis. By contrast, it would be positive according to Devereux and Engel's (2001) pricing-to-market hypothesis and/or Itagaki's (1980) hedging hypothesis. The share of productive capacity located abroad would also be positively affected by the increased volatility if Goldberg and Kolstad's (1995) theory of riskaverse foreign investor behavior is valid.

While these controversies about the relationship between exchange rate volatility and FDI assume a linear relation, recent studies imply a potential nonlinear relation. Sarkar (2000) suggests the possibility of nonlinearity in the uncertaintyinvestment relationship using a stochastic income model, although he does not explicitly consider the effect of exchange rates. However, Jeanneret (2007) shows Ushaped nonlinearity considering the effect of both exchange rate volatility and moneyness of the project. Darby et al. (1999) also examine a nonlinear relationship, arguing that rising volatility would either increase or decrease investment depending largely on the magnitude of the volatility, residual values of the project and opportunity cost of waiting.

In addition to the change in the level of the exchange rate, the volatility of the Korean currency, won, against major currencies increased after the crisis because the Korean government adopted a floating exchange rate regime in late 1997. For example, the average volatility of the won against the U.S. dollar after the crisis has been almost five times higher than it was before the crisis (see Table 1). Assuming that exchange rates are largely determined by the uncovered interest rate parity, the increased volatility in Korea following the crisis provides us with suitable material for investigating the relationship between exchange rate volatility and FDI.

[Table 1 around here]

\subsection{Exchange rate levels and FDI}

If the world were free of friction and exchange rate movements simply reflected the disparity in national prices between countries, real purchasing power parity (PPP) 
would be maintained and exchange rates would have little effect on MNEs' investment decisions. There is ample empirical evidence, however, to indicate that purchasing power parity often fails (Taylor and Taylor, 2004, and references therein). As a result, exchange rate movements may be a determinant of foreign investment decisions. The changes in the level of the exchange rate can affect the decision making of MNEs in two respects. First, the exchange rate affects MNEs' operational incomes when the repatriated profits are converted into the currency of the source country. Second, it may also affect the strength of MNEs' effective demand in comparison with local competitors to acquire assets expressed in local currency.

Froot and Stein's model (1991), extended by Klein et al. (2002), focuses on the role of exchange rates and the wealth effect argument. Their model notes the reaction of international capital movements to the changes in wealth that are brought about by exchange rate fluctuations. The appreciation of the exchange rate enhances a domestic corporation's bidding power to purchase assets in another country. If the capital market is not perfectly integrated and free arbitrages are not permitted, this enhanced wealth and consequent bargaining power increase the ability of domestic corporations to acquire assets denominated in the depreciated currency. Similarly, Kogut and Chang (1996) suggest that exchange rate movement is an important determinant of FDI. Analysing Japanese electronic firms' investment in the U.S. in the 1970s and 1980s, they argue that the effect of exchange rate movement would be enhanced if the MNEs have $R \& D$ capability along with their previous history of investment in the host country.

Krugman (1998), extended by Aguiar and Gopinath (2005), proposes a model explaining the fire-sale FDI in emerging markets. This model suggests that liquidityconstrained firms are forced to sell assets at a discount mainly to investors from high income countries that have deep pockets. An important implication of this fire-sale argument is that a sudden deviation of exchange rate from its long-run equilibrium level decreases delayability of the investment, which is similar to the implication of the real option based FDI hypothesis (e.g., Dixit and Pindyck, 1994).

Table 2 shows that the exchange rate of the Korean won against all major global currencies has increased. For example, the exchange rate of the won against the U.S. dollar rose sharply at the onset of the crisis, and the value of the won dropped by around 46 percent by early March 1998 compared to its 1996 level. 
[Table 2 around here]

Given imperfectly integrated capital markets across countries, as indicated by de Jong and de Roon (2005), the collapse in the value of the local currency (won) against major foreign currencies would have attracted more foreign investment in Korea from these countries. We hypothesize that the effect of the changes in the exchange rate level on FDI inflow would be positive, but the driving force may be different before and after the crisis. If the crisis was unpredictable, the sign of the coefficient of the exchange rate before the crisis should be positive and this would have been driven mainly by MNEs' operational income converted from the depreciated foreign currency. If Froot and Stein's (1991) wealth effect combined with Krugman's (1998) fire-sale hypothesis is valid, the coefficient of the exchange rate, measured by the amount of host country currency per source country currency, would be statistically significant with a positive sign, particularly after the crisis, when local firms faced severe liquidity constraints.

\section{The Empirical model}

Panel data analysis is beneficial to obtain consistent estimators in the presence of omitted variables and in the absence of good instrument variables. In contrast to existing estimations relying on either cross-section or time-series data, we note that unobservable time-constant, country-specific factors or heterogeneous foreign investors' (unobservable) behaviors can affect FDI flows. As such, we employ an unobserved effects panel model (Chamberlain, 1984; Wooldridge, 2002) for our analyses: ${ }^{4}$

$$
\begin{aligned}
& \text { FDI_to_ } \text { Korea }_{i t}=\mathbf{x}_{i t}^{\prime} \boldsymbol{\beta}+\gamma \text { EXRATE }_{i t}+\xi_{i t}, \\
& \xi_{i t}=v_{i}+\varepsilon_{i t},
\end{aligned}
$$

where $i$ indexes the individual source country and $t$ indexes the time period. The unobserved effect $v_{i}$ in the composite residuals $\xi_{i t}$ is the individual fixed effect, and

\footnotetext{
${ }^{4}$ We assume homogenous effect of exchange rate across the industries due to unavailability of industrylevel FDI data.
} 
this random variable indicates the time-invariant country fixed effect. The public's hostile or friendly attitude towards multinational enterprises' (MNEs) business in the home country is an example of this heterogeneity. $\mathbf{x}_{i t}$ denotes a vector of time-varying observed independent variables excluding the exchange rate variable, EXRATE, and $\varepsilon_{i t}$ denotes a time-varying unobserved idiosyncratic error term.

Since we intend to examine the changes in MNEs' investments in Korea before and after the 1997 financial crisis in anticipation of a structural change around 1997, we extend the model (1) in two ways. First, we estimate the same model (1) for two different groups (i.e., periods):

FDI_to_Korea ${ }_{i t}=\mathbf{x}_{i t}^{\prime} \boldsymbol{\beta}^{A}+\gamma^{A} E X R A T E_{i t}+\xi_{i t}$, if $t \in\{G 1$ : before the crisis, 1981-1996 $\}$,

FDI_to_Korea ${ }_{i t}=\mathbf{x}_{i t}^{\prime} \boldsymbol{\beta}^{B}+\gamma^{B}$ EXRATE $_{i t}+\xi_{i t}$, if $t \in\{G 2:$ after the crisis, 1997-2006 $\}$,

where the EXRATE variable indicates exchange-related variables such as exchange rate volatility and level data. We call model (2) the two-group model. One of the advantages of this two-group analysis is that we can directly compare the estimated parameters before and after the financial crisis.

The other extension of model (1) entails including a binary variable for the financial crisis and an interaction variable between the EXRATE and this binary variable:

$$
\begin{aligned}
& \text { FDI_to_Korea }{ }_{i t}=\mathbf{x}_{i t}^{\prime} \boldsymbol{\beta}+\gamma E X R A T E_{i t}+\lambda D_{\text {crisis }}+\delta E X R A T E \times D_{\text {crisis }}+\xi_{i t}, \\
& D_{\text {crisis }}=\left\{\begin{array}{ll}
0, & \text { if } t \in\{1981-1996\}, \\
1, & \text { if } t \in\{1997-2006\} .
\end{array} \text { or } \quad D_{\text {crisis }}= \begin{cases}1, & \text { if } t \in\{1997-1998\}, \\
0, & \text { otherwise. }\end{cases} \right.
\end{aligned}
$$

We call this model (3) the crisis dummy variable model. The advantage of this model is that it is possible to investigate the channel of how EXRATE affects FDI. A significant coefficient of the interactive variable $\delta$ implies that the EXRATE variable affects FDI inflows through the crisis event. ${ }^{5}$ In contrast, the significance of $\lambda$ suggests a direct

\footnotetext{
${ }^{5}$ As a referee suggests, the difference-in-difference method is another way to examine the 'causal effect'. Further, the treatment regression method and regression discontinuity design method are
} 
effect of the crisis event per se on FDI inflows. ${ }^{6}$ Another merit of model (3) is that we can investigate the duration of the effect of EXRATE on FDI by defining $D_{\text {crisis }}$ differently.

\section{Data}

The data include Korea's eight major FDI source countries in three different regions in the world: the U.S. and Canada in North America, Japan and Singapore in Asia, and Germany, the U.K., France and Switzerland in Europe. The average share of the aggregated eight countries' FDI in the total FDI into Korea was around 76 percent over the sample period. Figure 1 shows that U.S. and Japanese investment led FDI inflows, although the Japanese share has declined since the mid-1980s, whereas U.S. investment has fluctuated around 32 percent.

[Figure 1 around here]

In order to improve the robustness of the estimations, we use two types of FDI variable: real FDI (FDI_REAL), measured by the natural logarithm of the nominal FDI (in U.S. dollars) converted in 1995 constant value, and the share of the individual country (i)’s FDI in Korea’s GDP (FDI_GDPK), measured by FDI(i)/GDP Korea. The share variable is motivated by Goldberg and Kolstad (1995), who demonstrate that the

\footnotetext{
frequently used alternative methods for the causal effect. However, the identification of the (mean) coefficient to capture the effect requires a large number of (cross-sectional) observations (Angrist, 2001), which is beyond availability in our case. We would like to make the following two observations regarding the concern about the possible estimation bias associated with reversed causality. First, the crisis in Korea is regarded largely exogenous (Kawai, 2000) while the exogeneity of the origin (i.e., Thailand) can be debated. This is true particularly for the triggering of the crisis. The V-shaped recovery of the economies in the region also supports this argument. This implies that FDI flows did not cause the crisis. Rather, the opposite is true. And the main topic of this paper is to examine the role of exchange rate volatility and levels in the determination of multinational enterprises' (MNEs) investments (FDI) using the data of Korea. As we describe in the introduction, this exogeneity differentiates our sample from most existing studies dealing with exchange rate volatility caused by money supply shocks.

Second, the crisis caused a sharp depreciation (of about 46 percent by early March 1998 compared to its 1996 level) of the Korean currency won against major currencies. Following the change in exchange rate system to the floating system, FDI inflows could have helped to appreciate the Korean won. In this sense, FDI could have reversely affected exchange rate. However, the reversal of the value of Korean won in the capital market following the crisis was largely due to the sustained high interest rate following the recommendation of the IMF.

${ }^{6}$ The total impact of the crisis period should include the second-order impact, measured by $\delta$ EXRATE .
} 
share of productive capacity located in a foreign market is a function of the exchange rate variable.

We measure exchange rate volatility mainly by two different methods. First, we take a moving average of the standard deviation of the nominal exchange rate with a window of a two-month period, VOLATILITY_SDM. Second, we calculate the projected variance from a GARCH $(1,1)$ estimate for exchange rate returns. We also calculate the squared exchange rate variable to investigate nonlinearity in the uncertainty-investment relationship.

We use two different bilateral exchange rates in relation to the level data. One is the nominal rate, EXRATE_N, calculated by the number of units of host country currency per unit of source country currency, and the other is the real exchange rate, EXRATE_REAL, measured by adjusting the nominal rate by the ratio of the CPI index.

The data are obtained from various sources. The value of FDI is taken from the figures for FDI expressed in U.S. dollars provided by the Korean government, and the CPI index is from International Financial Statistics (IFS), produced by the International Monetary Fund. The exchange rate variable is obtained from the University of British Columbia (Pacific Exchange Rate Service).

In addition, we use several explanatory (control) variables as components of $\mathbf{x}_{\text {it }}$ in (1) (3). Trade figures are from the Korea Trade Association (Trade Statistics). The data for labor strikes are calculated to capture both push and pull factors by the ratio of the total number of strikes per year (normalized by the number of workers) in the source countries to those in the host country. Similarly, wage rate difference, WAGE_DIFF, is calculated by the wage rate from the wage index expressed in 1995 data in the source countries, divided by the wage rate in the host economy. Raw data for the labor variable are from the Yearbook of Labor Statistics (YLS) produced by the International Labor Organization.

In order to control for the possible effect of bilateral investment treaties, BIT, on FDI flows (Tobin et al., 2005, 2006; Neumayer et al., 2005), we also include the number of Korea's bilateral investment treaties with OECD countries. Cross-country mergers and acquisitions have been an important type of FDI since the late 1990s (Evenett, 2003; Rossi et al., 2005). Our database includes equity market return, measured by changes in the Korea Stock Price Index (KOSPI), which is expressed using 1995 values as a basis. Political risk is an important determinant of FDI (Clark, 
1997). Political risk, as an important investment risk for MNEs’ foreign investments, includes two indexes: the government stability index, GS, and the investment profile index, IP. Other control variables include Korea's exports to source countries, EXPORT; imports from source countries, IMPORT; total trade/GDP of Korea, OPENNESS; difference in frequencies of labor disputes, STRIKE_RATIO; wage difference between source countries and Korea, WAGE_DIFF; Korea's real GDP per capita, CGDP; and output per employee in Korea, OUTPUT. Following Swenson (1994), we include the difference in (highest) corporate tax rates between source and host countries as an additional control variable, TAX_DIFF. All nominal level data in this study are converted into real terms using CPI. In Table 3, we summarize the definitions and sources for all the variables we use in this study.

[Table 3 around here]

\section{Empirical results}

\subsection{Preliminary results}

The null hypothesis of i.i.d. errors against the presence of the individual specific effect is rejected at the 1 percent significance level by the Breusch-Pagan LM test version of the F-test, which strongly supports our choice of the unobserved effects model.

While the Hausman test supports both fixed effects (FE) and random effects (RE) models depending on the model specifications, this paper focuses on the RE model for the following two reasons. First, we assume $v_{i}$ is a cluster specific random element, and as major FDI source countries in Korea the eight countries are randomly selected from a large population. Second, our estimation model includes regressors that do not vary much over time.

The Augmented Dicky-Fuller and Phillip-Perron tests show the presence of a unit root for most of the macroeconomic variables, including all exchange rates, trade variables, and GDP per capita. The unit root tests yield a mixed result for the FDI variable. We cannot reject the null hypothesis of a unit root for ln (real FDI), whereas 
we do reject the null hypothesis for the share of FDI in Korea's GDP at the conventional significance level. However, the null hypothesis of a unit root is rejected at the five percent significance level for ln (real FDI) variables and EXPORT. As a result, we differentiate all the unit root variables but use level data for the remaining data.

In addition, given the general nature of the error terms in (1)-(3), we report standard errors in the estimation that are robust to heteroskedasticity and autocorrelations.

\subsection{Estimation results for the entire sample period}

We notice that Korea experienced the financial crisis around 1997 in the wave of the Asian financial crisis accompanied by the collapse of the value of the Korean won against major foreign currencies. Hence, as a preliminary step, we examine the possibility of the heterogeneity of coefficients before and after the crisis by conducting the Chow test for the model with exchange rate volatility, whose results are reported in Table 4. The null hypothesis of the absence of the structural change is rejected in favor of the heterogeneous two-group model by all the Chow tests for the different models using different measures of exchange rate volatility: observed data (i.e., moving averaged standard deviation, VOLATILITY_SDM) or predicted variance by the GARCH estimate, VOLATILITY_GARCH. The null hypothesis is also rejected by the Chow test for the model including squared volatility, VOLATILITY_GARCH^2, at the conventional significance level. As a result, we estimate the two groups (before and after the 1997 crisis) separately.

[Table 4 around here]

We also test for a unit root in variables for both before and after the financial crisis. We cannot reject the null of a unit root in most macroeconomic variables, including both nominal and real exchange rates, trade data, real FDI, and GDP related data, particularly before the crisis. However, the null of unit root in real FDI and export variables is rejected for the post-crisis period. The null of the unit root in exchange rate volatility is also rejected at the conventional significance level. As a result, we use the 
differenced real value of FDI (FDI_REAL), exchange rate level (EXRATE_N, EXRATE_REAL), IMPORT, OPENNESS, CGDP, OUTPUT, and KOSPI for both before and after the crisis, but the non-differenced share of FDI in Korea's GDP (FDI_GDPK), exchange rate volatility (EXRATE_SD, EXRATE_SDM) and the rest of the variables for both periods of time. The non-stationarity of EXPORT after the crisis was not clear, although the null of a unit root before the crisis is not rejected. Thus, we use the differenced EXPORT variable before the crisis, but both differenced and nondifferenced EXPORT after the crisis. ${ }^{7}$

\subsection{Volatility of the exchange rate}

Having noticed that the reliability of the estimated coefficients using observed volatility variable would be diminished to the extent that other missing control variables are also important in explaining FDI, we estimate the two-group model including a number of control variables. ${ }^{8}$ The estimation results in Table 5 confirm that the investment strategies of major MNEs in Korea changed when the volatility of the exchange rate increased after the crisis. We measure exchange rate volatility as the moving averaged standard deviations with a two-month time window, VOLATILITY_SDM. All the coefficients of the volatility variables become statistically significant with negative signs following the crisis (column 2). Before the crisis, the sign of the volatility coefficients are not significant (column 1).

[Table 5 around here]

\footnotetext{
${ }^{7}$ Given the unit root test results for the EXPORT variable, we estimate models using both differenced and non-differenced EXPORT variables during the post-crisis period. We find little change in the estimation results.

${ }^{8}$ We begin with the estimation of the two-group model using the observed exchange rate variable as a single regressor, excluding other explanatory variables. The advantage of using realized exchange rate data is that one can directly use statistical concepts such as standard deviation. The estimation results based on the two-group models using the real value of FDI (FDI_REAL) as the dependent variable and exchange rate volatility (i.e., EXRATE_SD or EXRATE_SDM) as a single regressor. The volatility variable shows a significant negative coefficient only after the crisis but an insignificant positive before the crisis. This result is robust to the measures of exchange rate volatility (i.e., EXRATE_SD and EXRATE_SDM). This implies that MNEs' investment behavior is negatively affected by increased volatility following the 1997 financial crisis in Korea. The output is available upon request.
} 
This finding is consistent with at least two different hypotheses. First, according to the option-based hypothesis (Pindyck, 1998; Dixit and Pindyck, 1994; Campa, 1993), currency volatility delays the entry of multinational firms because volatility increases the option value associated with waiting before incurring the sunk costs necessary to produce in a foreign country. Exchange rate uncertainty has increased since the 1997 Asian financial crisis, due partly to the introduction of floating exchange rates by all the countries that experienced the crisis, except for Malaysia (Kawai, 2000).

Second, reduced consumer confidence due to increased uncertainty of income flows might be the reason. Gupta et al. (2007) show that economies that experienced capital inflows in the years prior to the crisis or an increase in their external debt burden during the crisis were more likely to slow down during the crisis. The existing literature argues that the failure of corporate monitoring and control leads to managerial problems, whereby an excessive level of inefficient investment and a high debt-equity ratio are perpetuated in the crisis-hit countries, including Korea (Borensztein and Lee, 1999; Corsetti et al., 1999). In fact, Korea experienced negative 6.9 percent growth in 1998, although this was followed by a quick recovery in the growth rate. Having noted the reduced size of the market, coupled with the increased exchange rate risk, foreign investors may have deferred their investment decisions. Alternatively, we can interpret the result as suggesting that higher exchange rate volatility could have reduced the certainty-equivalent expected profit, which is used in the expected NPV of current investment decisions.

Instead of the real value of FDI (FDI_REAL), we continue the examination of the relationship between FDI and exchange rate volatility using the share of FDI in Korea's GDP as an alternative dependent variable, whose estimation results are also presented in Table 5 (columns 3 and 4). The results in columns 3 and 4 are consistent with those in columns 1 and 2 in Table 5 in that the coefficients of the exchange rate volatility variables become negative following the crisis, while they are insignificantly positive before the crisis. However, we notice that the negative coefficients of exchange rate volatility are marginally significant following the crisis, and the explanatory power for the FDI share model is substantially lower than that for the FDI_REAL model, which is indicated by a significant decline in $R^{2} \mathrm{~s}$ for the FDI share 
model both before and after the crisis. This implies that the FDI share variable is loosely related to exchange rate volatility and other explanatory variables. ${ }^{9}$

\subsection{A further investigation on the role of exchange rate volatility}

Armed with observations described above, we now investigate the volatilityFDI relationship further. First, we examine the channel of how exchange rate volatility affects FDI inflows. Does it affects FDI directly or combined with the effect of the financial crisis? As discussed in the model section, Section 3, one of the merits of the dummy variable model in comparison with the two-group model is that it enables us to investigate interaction between exchange rate volatility and the financial crisis.

Second, we also analyze the potential nonlinearity in the volatility-FDI relationship, as described in Section 2. In order to address this concern, we need to include a squared volatility variable (VOLATILITY^2) in the estimation model after we confirm the concavity using a non-parametric (i.e., LOWESS) plot. ${ }^{10}$ The analysis based on observed exchange rate movement is convenient because one can use statistical concepts such as standard deviation or variance directly as a proxy for the volatility. However, the squared standard deviation is variance by definition. Furthermore, the nature of volatility is intrinsically unobservable. Hence, we use the predicted variance of exchange rate return from our GARCH estimate as an alternative to the observed exchange rate. Table 6 shows that mean values of this unobserved (latent) volatility for the post-crisis period are higher than those for the pre-crisis. This pattern of change in volatility is consistent with the findings in Table 1, which uses the mean values of observed exchange rate volatility.

[Table 6 around here]

In Table 7, we report estimation results of the dummy variable model using conditional variance as a measure of exchange rate volatility. The dependent variable is the same real value of FDI (FDI_REAL) as before. The first two columns of the table report estimates including the volatility variable only. In order to investigate the nonlinear uncertainty-investment relationship, columns 3-4 report estimates including

\footnotetext{
${ }^{9}$ Please note that both IP and GS variables are proxying the political risk of international investment.
} 
the volatility variable and its squared term. We define the binary variable differently, depending on the expected duration of the effect of the crisis. In the long-run effect model, CRISIS97_06 denotes 1 if time belongs to the post financial crisis period and 0 otherwise. This is to measure the long run effect of the crisis. In the short-run model, CRISIS97_98 is 1 if time belongs to 1997-1998 and 0 otherwise. This is to examine the direct effect of the financial crisis during the turmoils.

\section{[Table 7 around here]}

We observe from Table 7 that the volatility effect seems to prevail for some time, as the volatility and interaction variables are significant only for the long-run (LR) model (columns 1 and 3). The negative relationship between exchange rate volatility and FDI inflows is shown via an interactive effect with the financial crisis in the long-run model (CRISIS97_06*VOLATILITY). However, the direct effect of VOLATILITY, measured by conditional variance, is somewhat obscured. It is significant only in the LR model as well (columns 1 and 3). However, the sign of the coefficient is mixed, depending on whether we include VOLATILITY^2. The estimated coefficient of this volatility variable is negative and significant at the conventional level when the model includes a squared volatility variable, whereas the variable is marginally significant with a positive sign when the model excludes the squared volatility variable. The option-based FDI theory indicates that MNEs would invest only if the present value of a project reaches beyond a critical level, given uncertainty. Dixit (1989) dubbed this MNEs’ investment behavior as FDI-hysteresis.

We also observe that the squared volatility variable is significantly positive in the long-run model (column 3), which supports a nonlinear relationship between uncertainty and investment argued by Sarkar (2000). Sarkar (2000) proposes a nonlinear relationship between uncertainty and FDI in that a higher uncertainty changes the probability that the threshold level of the triggering investment will be reached before a specific date. The interaction variable between the volatility and binary variables for the crisis is significantly negative for the LR (i.e., the binary for '97-`06) model, but not for the SR ('97-'98) model. This implies that the negative effect of volatility (i.e., increasing waiting value when uncertainty increases as the real option

\footnotetext{
${ }^{10}$ We appreciate a referee’s suggestion.
} 
theory suggested) is persistent and needs to be understood in combination with the effects of the crisis. This explanation is supported by the estimated coefficient of the crisis variable, which is significant only in the LR model.

In order to investigate this nonlinearity relation between investment and uncertainty further, we include exchange rate volatility variables as well as exchange rate level variables in the dummy-variable model, whose estimation results are presented in Table 8. We find that the effect of increased volatility seems to affect MNEs investment behavior over time as indicated by significant coefficients of interaction variables in the LR effect model (i.e., columns 1 and 3). The results also support nonlinearity in the uncertainty-investment relationship in the LR effect model (column 3). The coefficient of the VOLATILITY variable is significant only when we consider this uncertainty, coupled with the VOLATILITY^2 variable, regardless of model specification. This implies that volatility should be understood better in the nexus of the nonlinear relationship between FDI and uncertainty. The results also suggest that this nonlinearity in the uncertainty-investment relationship needs to be interpreted with some time lags, considering the reality that implementation of foreign investments often takes time. In addition, it is noted that the exchange rate level variable is not significant in any model we consider in Table $8 .^{11}$

[Table 8 around here]

\subsection{A further investigation on the role of exchange rate levels}

As a preliminary step, we test for structural change in the model when we use exchange rate level variables. The Chow test results in Table 9 strongly support the structural change and the two-group model regardless of the choice of dependent variables and exchange rate variables.

[Table 9 around here]

\footnotetext{
${ }^{11}$ We examine lag effects of exchange rate movement (i.e., level) by including first difference between exchange rate and its squared variables. However, none of these variables is significant at the conventional level. The Chi-square (2) statistic is 0.02, and thus it cannot reject the null of joint zeros of the two coefficients. To conserve space, we do not report the detailed estimation results, which are available from the authors.
} 
As in the case of exchange rate volatility, we estimate the two-group model using exchange rate level data. Similar to the exchange rate volatility case, the estimation results of the real FDI model, reported in Table 10, support that MNEs investment behavior changed following the crisis. Furthermore, the results imply a nonlinear relationship between exchange rate level and FDI. The quadratic form of the variable is significant at the conventional significance level only after the crisis (columns 2 and 4). This result is robust to the use of both nominal exchange rate volatility (EXRATE_N^2) and real exchange rate volatility (EXRATE_REAL^2).

[Table 10 around here]

The wealth effect hypothesis (Froot and Stein, 1991) suggests that nations suffering from a dramatic deviation of the value of the country's currency from its equilibrium value would attract more foreign investment. Given imperfect global financial markets and limited arbitrage, the theory argues that appreciation of the source country's currency increases the bargaining power of MNEs relative to local competitors. In fact, many indebted Korean firms suffered from severe liquidity constraints following the crisis due largely to soaring market interest rates under the IMF regime and reduced consumer confidence (Kawai, 2000).

An alternative interpretation of the negative, significant nominal exchange rate volatility (EXRATE_N^2) and real exchange rate volatility (EXRATE_REAL^2) would be that these variables may proxy exchange rate volatility. Then, this finding is consistent with those observed above using other measures of exchange rate volatility such as VOLATILITY_SDM. ${ }^{12}$

In Table 11, we report the estimation results for the crisis dummy model using exchange rate level data. ${ }^{13}$ The estimation results uncover some interesting facts about

\footnotetext{
${ }^{12}$ To check the robustness of our findings, we conducted the estimation using FDI share in Korea's GDP as the dependent variables with the same vector of regressors. Estimation results are similar to those in Table 10 although the statistical significance of the estimated coefficient of the exchange rate level variable decreases. To save space, we do not report the results.

13 The cost of this RE in comparison with the FE model is to restrict 'all' independent variables to being uncorrelated with $v_{i}$. Russ (2007) also points out the possible endogeneity problem in the nexus of exchange rate-FDI in a general equilibrium framework. Although our model is largely based on a partial equilibrium model, we examine the validity of our estimation in the following two ways. First, in relation to the possible correlation between regressors and individual heterogeneity, Mundlak (1978), augmented by Chamberlain (1984), suggests the correlated random effects (RE) model. We find none of the timedemeaned variables is significant regardless of different estimation models. Second, we conduct
} 
the relationship between exchange rate movement (level) and FDI inflows. In contrast to the two-group model, exchange rate levels (both nominal, EXRATE_N, and real, EXRATE_REAL) became significant 'during' the crisis (columns 2 and 4). This suggests that a sharp depreciation of the value of the Korean won attracts more FDI only during the crisis. These exchange rate level variables are no longer significant by the end of 2006 (columns 1 and 3). This finding is persistent regardless of measurement of exchange rate level (i.e., both nominal, EXRATE_N, and real, EXRATE_REAL). This result is in line with the fire-sale FDI hypothesis put forward by Krugman (1998) and Aguiar and Gopinath (2005). The theory posits that nations suffering from dramatic misalignment of exchange rate levels trigger an increase in foreign investment.

[Table 11 around here]

Interestingly, this devaluation seems to have affected FDI flows without roundabout effects, as indicated by the insignificant coefficients of the interactive variable between the exchange rate and crisis dummies. This result is robust to model specifications. The crisis event variable is significant at the 5 percent level in the short run (column 2), but at the 10 percent level by the end of 2006 (column 1). This suggests a fading-away effect of the crisis event that is almost exhausted by the end of 2006 . This implies that misalignment of exchange rate levels as a determinant of FDI is effective only in the short run, which is in contrast with the persistent effects of exchange rate volatility discussed above in Section 5.4.

The results also indicate that the crisis and exchange rate levels affect FDI inflows not only independently (i.e., not through the interaction terms) but also in opposite directions. The exchange rate level has a positive effect on FDI inflows in the short run, confirming that the depreciation of the won against major currencies during 1997-98 attract FDI. In contrast, the crisis event per se has a negative effect. The actual FDI inflows are the net result of these two offsetting forces. This finding may provide a clue to the failure to uncover the effect of exchange rate levels on FDI inflows in the two-group estimation.

estimations using instrumental variables to allow for endogeneity of regressors in the equation. There are two major steps for this instrumental variable approach. First, we difference all variables in the equation to remove unobserved heterogeneity. Second, we create instrumental variables within the system to avoid endogeneity bias (Arellano, 2003; Wooldridge, 2002). The overall estimations support our findings, 


\section{Summary and concluding remarks}

In this paper, we have re-examined the role of exchange rate volatility and level in the determination of multinational enterprises' (MNEs) investments using the data of Korea, which experienced a severe financial crisis around 1997. The Korean experience is unique in that, after the financial crisis, Korea experienced a substantial devaluation of its currency together with a significant increase in its volatility. As such, the Korean experience provides a natural laboratory to re-examine the role of both exchange rate volatility and level in determining foreign direct investment.

Given mixed evidence in prior studies, we have paid special attention to finding robust empirical evidence on the relationship between FDI and exchange rate variables. Given strong evidence of structural change around 1997, we employ two empirical models to address the structural change: a two-group model and a crisis dummy variable model. We use two types of measures for FDI: level of FDI and its ratio to GDP. For exchange rate volatility, we use both observed data (i.e., moving averaged standard deviation) and GARCH-based prediction.

Our major findings can be summarized as follows. First, the behavior of foreign investors in Korea changed following the 1997 crisis. The coefficients of exchange rate variables (i.e., both volatility and level) are significant only after the crisis, but insignificant before the crisis. The change in FDI in response to exchange rate volatility is robust, while that to exchange rate level is quite mixed. Recent development of FDI theory based on the real option theory also implies that MNEs would consider the uncertainty-driven value of waiting in their decision-making process.

Second, the durations of the effect of exchange rate volatility and level on FDI are different. The interaction between the crisis dummy variable and exchange rate volatility is significant in the long run, whereas the interaction between the crisis dummy variable and exchange rate level is not significant either in the short run or in the long run. However, exchange rate levels are significant in the short run. This implies that the effect of exchange rate volatility on FDI is persistent, whereas that of misalignment of level is only temporary, suggesting that MNEs regard volatility as a

although the statistical significance of the exchange rate level becomes stronger and the statistical significance of the exchange rate volatility variable drops somewhat. 
more 'generic' determinant of foreign investment than misalignment of the exchange rate level.

Third, our estimation supports nonlinearity in the relation between uncertainty and investment, as suggested by Sarkar (2000) and Darby et al. (1999). We find strong evidence of a convex-type of nonlinearity between uncertainty and FDI, which is similar to Jeanneret (2007). The finding of nonlinearity is in contrast with the existing literature relying on a linear relationship. However, it is consistent with the recent development of option-based investment theory, which suggests a complicated relationship between uncertainty and investment. The central idea of this theory is that the effect of volatility on investment differs when MNEs consider the moneyness of the project (i.e., an out-of-the-money or in-the-money option), residual value of the project, and magnitude of the value-of-waiting investment and so on. Our finding supports this nonlinearity argument and may shed some light on why existing literature shows mixed results on the relation between exchange rate variables and FDI.

\section{Acknowledgements}

We would like to thank editor, Charles Cao, and two anonymous referees of this journal for their suggestions and comments. The referees' comments were very helpful to improve our original draft. Dr. Min also acknowledges the financial support from the Griffith University Research Grant. The usual disclaimer applies. 


\section{References}

Aizenman, J., 1992. Exchange rate flexibility, volatility and patterns of domestic and foreign direct investment. IMF Staff Paper 39, 890-922.

Aguiar, M., Gopinath, G., 2005. Fire-sale foreign direct investment and liquidity crisis. Review of Economics and Statistics 87(3), 439-52.

Aizenman, J., Marion, N., 2004. The merits of horizontal versus vertical FDI in the presence of uncertainty. Journal of International Economics 62, 125-148.

Angrist, J., 2001. Estimation of limited dependent variable models with dummy endogenous regressors: Simple strategies for empirical practices. Journal of Business and Economic Statistics 29(1), 2-15.

Arellano, M., 2003. Panel Data Econometrics, Oxford, Oxford University Press.

Aybar, B., Aysun, F., 2009. Cross-border acquisitions and firm value: an analysis of emerging-market multinationals. Journal of International Business Studies 40(8), 1317-1339.

Blonigen, B.A., 1997. Firm-specific assets and the link between exchange rates and foreign direct investment. American Economic Review 87(3), 447-465.

Blonigen, B.A., 2001. In search of substitution between foreign production and exports. Journal of International Economics 53, 81-104.

Borensztein, E., Lee, J-W., 1999. Credit allocation and financial crisis in Korea. IMF Working Paper \# 20.

Braconier, H., Norback, P-J., Urban, D. 2005. Multinational enterprises and wage costs: vertical FDI revisited. Journal of International Economics 67, 446-470.

Campa, J.M., 1993. Entry by Foreign Firms in the United States under Exchange Rate Uncertainty. Review of Economics and Statistics 75, 614-22.

Caves, R.E. 1989. Exchange-rate movements and foreign direct investment in the United States. in Audretsch, D.B., Claudon, M.P. (eds.), The internationalisation of U.S. markets. New York: New York University Press.

Chamberlain, G., 1984. Panel data. In Griliches, Z. and M.D. (eds.), Handbook of Econometrics, vol.2. Intriligator, Amsterdam: North Holland.

Clark, E., 1997. Valuing political risk. Journal of Money and Finance, 16(3), 477- 490.

Corsetti, G., Pesenti, P., Roubini, N., 1999. Paper tigers? A model of the Asian crisis. European Economic Review 43, 1211-1236. 
Cushman, D.O., 1985. Real exchange rate risk, expectations, and the level of direct investment. Review of Economics and Statistics 67, 297-308.

Cushman, D.O., 1988. Exchange-rate uncertainty and foreign direct investment in the United States. Weltwirtschaftliches Archiv 124, 322-335.

Darby, J., Hallett, A.H., Ireland, J., Piscitelli., L., 1999. The impact of exchange rate uncertainty on the level of investment. Economic Journal 109, C55-C67.

De Jong, F. and de Roon, F.A., 2005. Time-varying market integration and expected returns in emerging markets. Journal of Financial Economics 78, 583-613.

Devereux, M.B., and Engel, C., 2001. The optimal choice of exchange rate regime: Price-setting rules and internationalised production. NBER Working Paper, \# 6992.

Dixit, A., and Pindyck, R., 1995. The optimal approach to capital investment. Harvard Business Review (May/Jun), 105-15.

Dixit, A., and Pindyck, R., 1994. Investment under Uncertainty. Princeton University Press, Princeton, NJ.

Enright, M.J., 2009. The location of activities of manufacturing multinationals in the Asia-Pacific. Journal of International Business Studies 40(5), 818-840.

Evenett, S. J., 2003. The cross border mergers and acquisitions wave of the late 1990s. NBER Working Paper, WP9655.

Froot, K.A., Stein, J.C., 1991. Exchange Rates and Foreign Direct Investment: an imperfect capital markets approach. Quarterly Journal of Economics 106, 1191-1217.

Galgau, O., Sekkat, K., 2004. The impact of the single market on foreign direct investment in the European Union. in Michelis, L., Lovewell, M. (eds.), Exchange Rates, Economic Integration and the International Economy. APF Press, Toronto.

Goldberg, L.S., Kolstad, C.D., 1995. Foreign direct investment, exchange rate volatility and demand uncertainty. International Economic Review 36, 855873.

Gupta, P., Mishra, D., Sahay, R., 2007. Behavior of output during currency crises. Journal of International Economics. forthcoming.

Healy, P.M., Palepu, K.G., 1993. International corporate equity associations: who, where and why? in K.A., Froot (eds.), Foreign direct investment. Chicago: University of Chicago Press. 
Heston, A., Summers, R., and Aten, B., 2006. Penn World Table Version 6.2, Center for International Comparisons of Production, Income and Prices at the University of Pennsylvania.

ILO Yearbook of Labor Statistics, International Labor Organisation, various issues. IMF International Financial Statistics, International Monetary Fund, various issues.

Itagaki, T., 1981. The theory of the multinational firm under exchange rate uncertainty. Canadian Journal of Economics 14, 276-97.

Jeanneret, A., 2007, Foreign direct investment and exchange rate volatility: a nonlinear story, mimeo, Swiss Finance Institute, University of Lausanne.

Kawai, M., 2000. The resolution of the East Asian crisis: financial and corporate sector restructuring. Journal of Asian Economics 11, 133-68.

Klein, M.W., Peek, J., Rosengren, E.S., 2002. Troubled banks, impaired foreign direct investment: The role of relative access to credit. American Economic Review 92(3), 664-82.

Klein, M.W., Peek, J., and Rosengren, E.S., 1994. The real exchange rate and foreign direct investment in the United States: relative wealth vs. relative wage effects. Journal of International Economics 36(3-4), 373-89.

Kogut, B. and Chang, S.J., 1996. Platform investment and volatile exchange rate. Review of Economics and Statistics 78, 221-231.

Korea Trade Association, Trade Statistics, various issues.

Korea Securities Supervisory Board, 1997, Capital Market Yearly Statistics, Korea Securities Supervisory Board.

Krugman, P., 1998. Fire-sale FDI. paper presented for NBER Conference on Capital Flows to Emerging Markets, February 20-21; MIT mimeograph.

Lee, H.K., 1994. Foreign Direct Investment and Investment Policy (in Korean), Korea Development Institute, Seoul Korea.

Min, Byung S., 2006. Trade and foreign direct investment patterns in the Republic of Korea in the aftermath of the 1997 financial crisis. Asia-Pacific Trade and Investment Review 2 (1), 3-24.

Min, Byung S., 2010. Evaluation of board reform: The case of the appointment of outside director, Griffith University, mimeograph.

Mundell, R.A., 1957. International trade and factor mobility. American Economic Review 47, 321-355. 
Neumayer, E., Spess, L., 2005. Do bilateral investment treaties increase foreign direct investment to developing countries. World Development 33(10), 1567-1585.

Nocke, V., Yeaple, S., 2007. Cross-border mergers and acquisitions vs. Greenfield foreign direct investment: The role of firm heterogeneity. Journal of International Economics, forthcoming.

Pindyck, R.S., 1998. Irreversible investment, capacity choice, and the value of the firm. American Economic Review 78, 969-985.

Pindyck, R.S., 1991. Irreversibility, uncertainty, and investment. Journal of Economic Literature 29, 1110-1148.

Pulvino, T.C., 1998. Do asset fire sales exist?. An empirical investigation of commercial aircraft transaction. Journal of Finance 53, 939-78.

Ray, E.J., 1989. The Determinants of foreign direct investment in the United States: 1979-1985. in Feenstra, R. (eds.), Trade Policies for International Competitiveness, Chicago: University of Chicago Press.

Rivoli, P., Salorio, E., 1996. Foreign direct investment under uncertainty. Journal of Business Studies 335-357 (Second Quarter).

Rossi, S. Volpin, P.F., 2005. Cross-country determinants of mergers and acquisitions, Journal of Financial Economics 74(2), 277-304.

Russ, K.N., 2007. The endogeneity of the exchange rate as a determinant of FDI: A model of entry and multinational firms. Journal of International Economics 71(2), 344-372.

Sarkar, S., 2000. On the investment-uncertainty relationship in a real option model. Journal of Economic Dynamics and Control 24, 219-225.

Serven, L., 2003. Real-exchange rate uncertainty and private investment in LDCS. Review of Economics and Statistics 85(1), 212-218.

Swenson, D.L. (1994). Impact of U.S. tax reform on foreign direct investment in the United States. Journal of Public Economics 54(2), 243-66.

Taylor, A.M., Taylor, M.P., 2004. The purchasing power parity debate. NBER Working Paper \#10607.

Tcha, M. 1998. Labour disputes, factor intensity and direct foreign investment - the experience of Korea in transition. Economic Development and Cultural Change 46, 305-28.

Tobin, J. Rose-Ackerman, S., 2005. Foreign direct investment and the business environment in developing countries: The impact of bilateral investment 
treaties. Yale Law School Center for Law, Economics and Public Policy Research Paper \# 293.

Tobin, J. Rose-Ackerman, S., 2006. Bilateral investment treaties: Do they stimulate foreign direct investment? Yale Law School Center for Law, mimeo.

UNCTAD, 2001. World Investment Report 2001: Promoting Linkages, United Nations, NY and Geneva.

Wooldridge, J.M., 2002. Econometric Analysis of Cross Section and Panel Data, MIT Press: Cambridge.

Zhang, L.H., 2004. European integration and foreign direct investment. in Tsoukis, C., Agiomirgianakis,, G.M., Biswas, T. (eds.), Aspect of Globalisation: Macroeconomic and Capital Market Linkages in the Integrated World Economy. 


\section{Table1}

This table reports exchange rate volatility of the Won against major currencies before and after the 1997 crisis. Numbers are mean values of nominal exchange rates using monthly data for before (1981-1996) and after (1997-2006) the crisis. Figures in parentheses are standard deviations.

\begin{tabular}{lllllllll}
\hline & $\begin{array}{l}\text { US } \\
\text { (dollar) }\end{array}$ & $\begin{array}{l}\text { Canada } \\
\text { (dollar) }\end{array}$ & $\begin{array}{l}\text { Japan } \\
\text { (yen) }\end{array}$ & $\begin{array}{l}\text { Singapore } \\
\text { (dollar) }\end{array}$ & $\begin{array}{l}\text { Germany } \\
\text { (mark) }\end{array}$ & $\begin{array}{l}\text { UK } \\
\text { (pound) }\end{array}$ & $\begin{array}{l}\text { France } \\
\text { (franc) }\end{array}$ & $\begin{array}{l}\text { Swiss } \\
\text { (franc) }\end{array}$ \\
\hline Before & 11.46 & 11.55 & 0.26 & 9.94 & 18.99 & 62.18 & 5.95 & 25.94 \\
crisis & $\mathbf{( 7 . 6 )}$ & $\mathbf{( 4 . 1 )}$ & $(0.2)$ & $(5.8)$ & $(9.2)$ & $(34.1)$ & $(2.6)$ & $(12.4)$ \\
\hline After & 53.57 & 42.50 & 0.46 & 26.84 & 33.01 & 92.80 & 9.80 & 40.98 \\
crisis & $\mathbf{( 5 7 . 9 )}$ & $\mathbf{( 4 1 . 4 )}$ & $\mathbf{( 0 . 4 )}$ & $\mathbf{( 3 1 . 1 )}$ & $\mathbf{( 2 7 . 3 )}$ & $\mathbf{( 9 3 . 4 )}$ & $\mathbf{( 8 . 3 )}$ & $\mathbf{( 3 7 . 4 )}$ \\
\hline
\end{tabular}

\section{Table2}

This table report movements in the exchange rate of the Korean Won against major currencies before and after the 1997 crisis. Both nominal and real exchange rates are mean values for before (1981-1996) and after (1997-2006) the crisis. Numbers in parentheses are standard deviations. Measurement of real exchange rates is based on CPI.

\begin{tabular}{llllllllll}
\hline & & $\begin{array}{l}\text { US } \\
\text { (dollar) }\end{array}$ & $\begin{array}{l}\text { Canada } \\
\text { (dollar) }\end{array}$ & $\begin{array}{l}\text { Japan } \\
\text { (yen) }\end{array}$ & $\begin{array}{l}\text { Singapore } \\
\text { (dollar) }\end{array}$ & $\begin{array}{l}\text { Germany } \\
\text { (mark) }\end{array}$ & $\begin{array}{l}\text { UK } \\
\text { (pound) }\end{array}$ & $\begin{array}{l}\text { France } \\
\text { (franc) }\end{array}$ & $\begin{array}{l}\text { Swiss } \\
\text { (franc) }\end{array}$ \\
\hline Nominal \\
exchange & Before & 776.0 & 609.5 & 5.33 & 422.5 & 411.5 & 1245.7 & 127.0 & 486.2 \\
rate & crisis & $(60.5)$ & $(27.9)$ & $(1.7)$ & $(77.8)$ & $(91.7)$ & $(87.73)$ & $(20.3)$ & $(107.3)$ \\
\cline { 2 - 9 } & After & 1152.0 & 824.1 & 9.85 & 682.5 & 639.7 & 1890.6 & 190.7 & 804.3 \\
& crisis & $(144.4)$ & $(70.2)$ & $(1.1)$ & $(66.6)$ & $(80.8)$ & $(208.2)$ & $(24.2)$ & $(100.2)$ \\
\hline \multirow{2}{*}{ Real } & Before & 911.1 & 731.5 & 6.73 & 520.9 & 495.6 & 1336.3 & 152.4 & 569.2 \\
rate & crisis & $(116.7)$ & $(90.9)$ & $(1.3)$ & $(40.6)$ & $(60.3)$ & $(117.7)$ & $(17.6)$ & $(81.0)$ \\
\cline { 2 - 10 } & After & 1051.9 & 725.9 & 7.78 & 564.6 & 548.6 & 1739.8 & 163.1 & 657.6 \\
& crisis & $(27.9)$ & $(50.4)$ & $(1.2)$ & $(80.9)$ & $(66.9)$ & $(179.8)$ & $(20.2)$ & $(77.6)$ \\
\hline
\end{tabular}




\section{Figure1}

This figure shows share of eight major FDI source countries (in total) and the U.S. and Japan in FDI inflows into Korea. The Big 8 figure includes the US, Canada, Japan, Singapore, Germany, the UK, France and Switzerland.

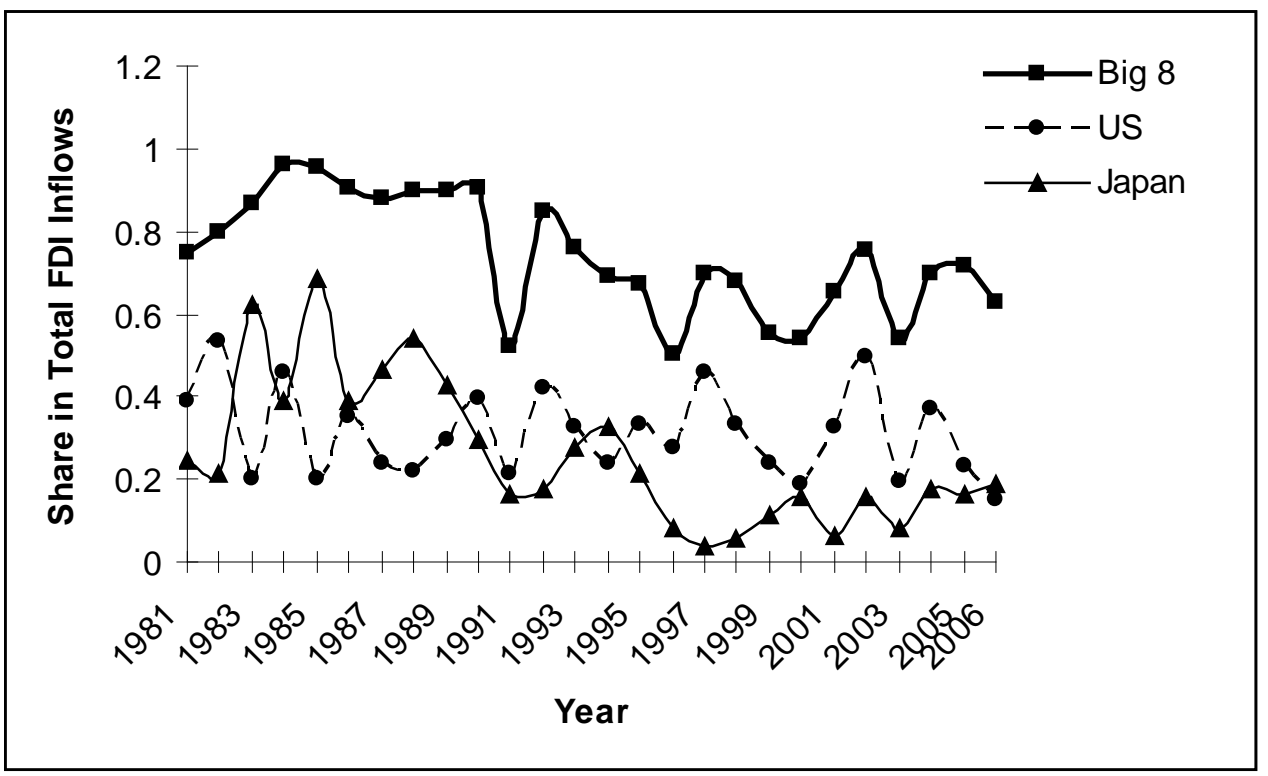




\section{Table 3}

This table reports summary of data. Definitions of included variables and their sources are FDI_REAL (log of real FDI in \$ thousand, MOCIE), FDI_GDPK (FDI/GDP_Korea, MOCEI), EXRATE_N (Number of units of Won per foreign currency divided by 100, Pacific Exchange Rate Service), EXRATE_REAL (Nominal exchange rate adjusted by CPI, Pacific Exchange Rate Service), VOLATILITY_SDM (Moving average with a 2 moth window, Pacific Exchange Rate Service), VOLATILITY (Projected variance by GARCH(1,1) estimate multiplied by 100, Model Estimate), BIT (Number of Korea's bilateral investment treaties with OECD countries, Neumayer et al. (2005)), GS (Government stability Index ranging from 0 (high risk) to 12 (low risk), Neumayer et al. (2005)), IP (Investment profile index ranging from 9(high risk) to 12 (low risk), Neumayer et al. (2005)), KOSPI (Return from Korea Exchange (Market Index), BOK and KSSB), EXPORT (log of export to FDI source country in \$Million), BOK and KTA), IMPORT (log of import from FDI source country in \$Million, BOK and KTA), OPENNESS (Total trade/GDP_Korea, BOK and KTA), STRIKE_RATIO (Days not worked in FDI source country/days not worked in Korea (Both are normalised by number of employment, YLS), WAGE_DIFF (Wage rate in FDI source country divided by wage rate in Korea, YLS), TAX_DIFF (Corporate tax rate in FDI source country divided by corporate tax rate in Korea, Business School, University of Michigan (interactive D.B.), CGDP (Real GDP per capital, Penn World Table 2006), OUTPUT (Real GDP/number of employment, IFS and YLS). MOCIE refers to the Ministry of Commerce, Industry and Energy in Korea; BOK refers to the Bank of Korea; KSSB refers to the Korea Securities Supervisory Board; KTA refers to the Korea Trade Association; YLS refers to the Yearbook of Labor Statistics published by the International Labour Organisation; IFS refers to the International Financial Statistics published by the IMF.

\begin{tabular}{|c|c|c|c|c|c|c|}
\hline \multicolumn{2}{|c|}{ Variable } & Mean & Std. Dev. & Min & Max & Obs \\
\hline FDI & FDI_REAL & 6.6 & 2.1 & -0.6 & 10.5 & 201 \\
\hline & FDI_GDPK & 8.9 & 15.4 & 0 & 85.9 & 208 \\
\hline Exchange & EXRATE $N$ & 6.9 & 4.1 & 0.9 & 23.1 & 208 \\
\hline $\begin{array}{l}\text { Level } \\
\text { Exchange }\end{array}$ & EXRATE REAL & 7.1 & 3.8 & 1.2 & 21.4 & 208 \\
\hline Rate & VOLATILITY_SDM & 28.0 & 38.3 & 1.7 & 340.0 & 208 \\
\hline Volatility & VOLATILITY & 1.4 & 0.55 & 0.55 & 4.07 & 208 \\
\hline BIT & & 10.1 & 3.6 & 6 & 15 & 176 \\
\hline G & & 7.6 & 1.1 & 5.9 & 10 & 152 \\
\hline$K O S P I$ & & 7.6 & 1.0 & 6 & 9.7 & 152 \\
\hline & & 0.22 & 0.48 & -0.99 & 1.46 & 207 \\
\hline IMDPT & & 3.3 & 1.3 & 0.4 & 5.9 & 208 \\
\hline OPFNNF & & 3.3 & 1.3 & -0.03 & 5.8 & 208 \\
\hline STRIKE_I & ITIO & 1.9 & 1.4 & -2.0 & 4.8 & 111 \\
\hline WAGF $D$ & & 24.5 & 104.6 & 0 & 924.3 & 196 \\
\hline$T A X \_D I F$ & & -6.7 & 10.8 & -22.8 & 64.3 & 207 \\
\hline & & 5.40 & 11.6 & -24.2 & 26 & 176 \\
\hline$C G D P$ & & 10.6 & 5.1 & 2.8 & 19.3 & 192 \\
\hline OUTPUT & & 1.7 & 0.6 & 0.7 & 2.8 & 208 \\
\hline
\end{tabular}




\section{Table 4}

This table reports results of the Chow test for structural change in parameters before and after the 1997 financial crisis (exchange rate volatility data). Regressors include exchange volatility variables (i.e., VOLATILITY_SDM, VOLATILITY_GARCH and its quadratic forms), GS, KOSPI, EXPORT, IMPORT, OPENNESS, STRIKE_RATIO, WAGE_DIFF, TAX_DIFF, CGDP, BIT and interactive variables between regressors and group dummy ( $\left.D_{\text {crisis }}\right)$.

Exchange Rate Volatility $\quad$ Real FDI as Dependent Variable FDI Share in GDP_KOREA as Dependent Variable

VOLATILITY_SDM

$$
\begin{array}{ll}
\chi^{2}(12)=29.55 & \chi^{2}(12)=92.07 \\
p>\chi^{2}=0.003 & p>\chi^{2}=0.000
\end{array}
$$

VOLATILITY_GARCH

$$
\begin{array}{ll}
\chi^{2}(12)=23.92 & \chi^{2}(12)=88.4 \\
p>\chi^{2}=0.02 & p>\chi^{2}=0.000
\end{array}
$$

VOLATILITY_GARCH^2
$\chi^{2}(12)=22.62$
$\chi^{2}(12)=88.3$
$p>\chi^{2}=0.03$
$p>\chi^{2}=0.000$ 
Table 5

This table reports results of estimation of the two-group model using exchange rate volatility. Time effects and constants are not shown. $R^{2}$ denotes within-group (overall) coefficient of determination. Pvalue under the coefficient is based on the heteroskedastic and autocorrelation efficient standard errors. Constants are not shown.

\begin{tabular}{|c|c|c|c|c|}
\hline \multirow[b]{2}{*}{ Variable } & \multicolumn{2}{|c|}{$\begin{array}{l}\text { Dependent variable is } \\
\text { FDI_REAL }\end{array}$} & \multicolumn{2}{|c|}{$\begin{array}{l}\text { Dependent variable is FDI } \\
\text { share in Korea's GDP }\end{array}$} \\
\hline & Before Crisis & After Crisis & Before Crisis & After Crisis \\
\hline \multirow{2}{*}{ VOLATILITY_SDM } & 0.002 & -0.003 & 0.052 & -0.038 \\
\hline & 0.4604 & 0.0477 & 0.5536 & 0.1169 \\
\hline \multirow{2}{*}{ EXPORT } & -2.132 & 0.163 & -5.053 & 21.166 \\
\hline & 0.015 & 0.052 & 0.4064 & 0.0445 \\
\hline \multirow[t]{2}{*}{ IMPORT } & 0.011 & -0.444 & 0.026 & 3.69 \\
\hline & 0.9911 & 0.3203 & 0.995 & 0.5142 \\
\hline \multirow[t]{2}{*}{ OPENNESS } & -0.016 & -0.028 & -0.046 & 0.798 \\
\hline & 0.409 & 0.8201 & 0.3353 & 0.4767 \\
\hline \multirow[t]{2}{*}{ STRIKE_RATIO } & 0.001 & 0.343 & -0.011 & -0.281 \\
\hline & 0.229 & 0.00 & 0.2032 & 0.7244 \\
\hline \multirow[t]{2}{*}{ TAX_DIFF } & -0.005 & -0.013 & 0.081 & 0.635 \\
\hline & 0.157 & 0.5864 & 0.5178 & 0.2951 \\
\hline \multirow[t]{2}{*}{ WAGE_DIFF } & -0.013 & 0.003 & -0.7 & 0.011 \\
\hline & 0.7517 & 0.9672 & 0.4029 & 0.9876 \\
\hline \multirow[t]{2}{*}{ IP } & & & 0.83 & 0.702 \\
\hline & & & 0.1315 & 0.856 \\
\hline \multirow[t]{2}{*}{ GS } & 0.281 & 0.367 & & \\
\hline & 0.0759 & 0.0114 & & \\
\hline \multirow[t]{3}{*}{ BIT } & -0.097 & -0.258 & & \\
\hline & & & -0.617 & 1.482 \\
\hline & 0.1847 & 0.004 & 0.4297 & 0.4893 \\
\hline Time Effects & Yes & Yes & Yes & Yes \\
\hline $\mathrm{N}$ & 100 & 48 & 104 & 48 \\
\hline$R^{2}$ & $0.33(0.32)$ & $0.44(0.45)$ & $0.12(0.12)$ & $0.26(0.12)$ \\
\hline
\end{tabular}

Table 6

This table reports mean value of exchange rate volatility measured by conditional variance. Prediction of conditional variance is based on the following GARCH estimate.

$$
\begin{aligned}
& Y_{t}=0.0236+\varepsilon_{t} \\
& \sigma^{2}=0.015+0.221 \varepsilon_{t-1}^{2}-0.287 \sigma_{t-1}^{2} \\
& (0.00)(0.11)
\end{aligned}
$$

Where, $Y_{t}$ is continuously compounded rate of change in exchange rate (i.e., $\ln ($ exchange rate, t) $\ln ($ exchange rate, $\mathrm{t}-1))$ and figures in the parentheses are standard errors.

\begin{tabular}{lllllllll}
\hline & US & Canadian & Japanese & Singapore & German & British & France & Switzerland \\
& Dollar & Dollar & Yen & Dollar & Mark & Pound & Franc & Franc \\
\hline $\begin{array}{l}\text { Before } \\
\text { Crisis }\end{array}$ & 0.0127 & 0.0124 & 0.0142 & 0.0126 & 0.0142 & 0.0134 & 0.0143 & 0.0145 \\
$\begin{array}{l}\text { After } \\
\text { Crisis }\end{array}$ & 0.0159 & 0.0146 & 0.0143 & 0.0144 & 0.0163 & 0.0164 & 0.0164 & 0.0163 \\
\hline
\end{tabular}


Table 7

This table reports results of estimation of the dummy variable model with volatility variable but excluding exchange rate level (dependent variable is FDI_REAL). Constant is not presented. $R^{2}$ refers to within group (overall) $R^{2}$. Volatility is measured by predicted sigma^2 from the GARCH estimate. P-value under the coefficient is based on the heteroskedastic and autocorrelation efficient standard errors. Constants are not shown.

\begin{tabular}{|c|c|c|c|c|}
\hline Variable & $\begin{array}{l}\text { Model1: Long Run } \\
\text { Effect1 }\end{array}$ & $\begin{array}{c}\text { Model1: Short Run } \\
\text { Effect }\end{array}$ & $\begin{array}{c}\text { Model2: Long Run } \\
\text { Effect }\end{array}$ & $\begin{array}{l}\text { Model2: Short Run } \\
\text { Effect }\end{array}$ \\
\hline \multirow[t]{2}{*}{ VOLATILITY } & 0.549 & 0.164 & -1.384 & -0.700 \\
\hline & 0.0986 & 0.3411 & 0.0195 & 0.4841 \\
\hline \multirow[t]{2}{*}{ VOLATILITY^2 } & & & 0.489 & 0.192 \\
\hline & & & 0.0008 & 0.3942 \\
\hline \multirow[t]{2}{*}{ CRISIS97_06 } & 1.878 & & 2.416 & \\
\hline & 0.0378 & & 0.0067 & \\
\hline \multirow[t]{2}{*}{ CRISIS97_06*VOLATILITY } & -0.670 & & -1.124 & \\
\hline & 0.0351 & & 0.0012 & \\
\hline \multirow[t]{2}{*}{ CRISIS97_98 } & & 1.927 & & 1.533 \\
\hline & & 0.2516 & & 0.4186 \\
\hline \multirow[t]{2}{*}{ CRISIS97_98*VOLATILITY } & & -1.665 & & -1.390 \\
\hline & & 0.234 & & 0.3625 \\
\hline \multirow[t]{2}{*}{ EXPORT } & -0.624 & -0.826 & -0.465 & -0.764 \\
\hline & 0.4103 & 0.355 & 0.564 & 0.4087 \\
\hline \multirow[t]{2}{*}{ IMPORT } & 0.449 & 0.628 & 0.292 & 0.61 \\
\hline & 0.3615 & 0.2506 & 0.5755 & 0.2717 \\
\hline \multirow[t]{2}{*}{ OPENNESS } & 0.003 & 0.002 & -0.001 & 0.002 \\
\hline & 0.7663 & 0.8057 & 0.9142 & 0.7666 \\
\hline \multirow[t]{2}{*}{ STRIKE_RATIO } & -0.002 & -0.003 & -0.002 & -0.002 \\
\hline & 0.0238 & 0.022 & 0.024 & 0.0196 \\
\hline \multirow[t]{2}{*}{ CGDP } & 0.643 & 0.635 & 0.624 & 0.616 \\
\hline & 0.0176 & 0.073 & 0.0538 & 0.1044 \\
\hline \multirow[t]{2}{*}{ TAX_DIFF } & 0.019 & 0.02 & 0.019 & 0.02 \\
\hline & 0.3124 & 0.2756 & 0.3113 & 0.2742 \\
\hline \multirow[t]{2}{*}{ WAGE_DIFF } & 0.02 & 0.052 & 0.025 & 0.053 \\
\hline & 0.5341 & 0.1654 & 0.487 & 0.1717 \\
\hline \multirow[t]{2}{*}{ KOSPI } & 0.292 & 0.371 & 0.16 & 0.262 \\
\hline & 0.2068 & 0.0015 & 0.4986 & 0.1572 \\
\hline \multirow[t]{2}{*}{ GS } & 0.452 & 0.626 & 0.495 & 0.622 \\
\hline & 0.0019 & 0.00 & 0.0042 & 0.00 \\
\hline \multirow[t]{2}{*}{ BIT } & 0.13 & 0.181 & 0.127 & 0.173 \\
\hline & 0.0575 & 0.00 & 0.0543 & 0.00 \\
\hline $\mathrm{N}$ & 150 & 150 & 150 & 150 \\
\hline$R^{2}$ & $0.55(0.33)$ & $0.53(0.32)$ & $0.55(0.35)$ & $0.53(0.32)$ \\
\hline
\end{tabular}




\section{Table 8}

This table reports results of estimation of the dummy variable model with exchange rate volatility and level (dependent variable is FDI_REAL). Constant is not presented. $R^{2}$ refers to within group (overall) $R^{2}$. Volatility is measured by predicted sigma^2 from the GARCH estimate. P-value under the coefficient is based on the heteroskedastic and autocorrelation efficient standard errors. Constants are not shown.

\begin{tabular}{|c|c|c|c|c|}
\hline Variable & Model1: Long Run Effect & Model1: Short Run Effect & $\begin{array}{l}\text { Model2: Long Run } \\
\text { Effect }\end{array}$ & $\begin{array}{l}\text { Model2: Short } \\
\text { Run Effect }\end{array}$ \\
\hline \multirow[t]{2}{*}{$\begin{array}{l}\text { EXRATE_N } \\
\text { (Exchange rate level) }\end{array}$} & 0.026 & 0.167 & 0.071 & 0.193 \\
\hline & 0.8645 & 0.1674 & 0.618 & 0.1262 \\
\hline \multirow[t]{2}{*}{ VOLATILITY } & 0.539 & 0.179 & -1.480 & -0.876 \\
\hline & 0.1108 & 0.3117 & 0.03 & 0.3807 \\
\hline \multirow[t]{2}{*}{ VOLATILITY^2 } & & & 0.506 & 0.235 \\
\hline & & & 0.0013 & 0.3006 \\
\hline \multirow[t]{2}{*}{ CRISIS97_06 } & 1.863 & & 2.394 & \\
\hline & 0.0361 & & 0.0066 & \\
\hline \multirow[t]{2}{*}{ CRISIS97_06*VOLATILITY } & -0.652 & & -1.091 & \\
\hline & 0.0574 & & 0.0037 & \\
\hline \multirow[t]{2}{*}{ CRISIS97_98 } & & 2.809 & & 2.467 \\
\hline & & 0.105 & & 0.194 \\
\hline \multirow[t]{2}{*}{ CRISIS97_98*VOLATILITY } & & -2.463 & & -2.252 \\
\hline & & 0.106 & & 0.166 \\
\hline \multirow[t]{2}{*}{ EXPORT } & -0.613 & -0.777 & -0.427 & -0.694 \\
\hline & 0.3967 & 0.3608 & 0.58 & 0.433 \\
\hline \multirow[t]{2}{*}{ IMPORT } & 0.442 & 0.589 & 0.268 & 0.561 \\
\hline & 0.3551 & 0.2664 & 0.6041 & 0.2975 \\
\hline \multirow[t]{2}{*}{ OPENNESS } & 0.003 & 0.002 & 0.00 & 0.003 \\
\hline & 0.7687 & 0.8004 & 0.9759 & 0.7546 \\
\hline \multirow[t]{2}{*}{ STRIKE_RATIO } & -0.002 & -0.002 & -0.002 & -0.002 \\
\hline & 0.0054 & 0.0215 & 0.0068 & 0.0194 \\
\hline \multirow[t]{2}{*}{ CGDP } & 0.676 & 0.766 & 0.714 & 0.762 \\
\hline & 0.0438 & 0.0596 & 0.0394 & 0.0659 \\
\hline \multirow[t]{2}{*}{ TAX_DIFF } & 0.019 & 0.021 & 0.019 & 0.021 \\
\hline & 0.3131 & 0.2421 & 0.3067 & 0.2383 \\
\hline \multirow[t]{2}{*}{ WAGE_DIFF } & 0.019 & 0.048 & 0.022 & 0.048 \\
\hline & 0.6003 & 0.1902 & 0.5795 & 0.2069 \\
\hline \multirow[t]{2}{*}{ KOSPI } & 0.298 & 0.448 & 0.172 & 0.326 \\
\hline & 0.1744 & 0.0002 & 0.4431 & 0.0529 \\
\hline \multirow[t]{2}{*}{ GS } & 0.454 & 0.667 & 0.504 & 0.669 \\
\hline & 0.0013 & 0.00 & 0.0027 & 0.00 \\
\hline \multirow[t]{2}{*}{ BIT } & 0.129 & 0.185 & 0.124 & 0.176 \\
\hline & 0.0704 & 0.00 & 0.0737 & 0.00 \\
\hline $\mathrm{N}$ & 150 & 150 & 150 & 150 \\
\hline$R^{2}$ & $0.56(0.34)$ & $0.54(0.32)$ & $0.56(0.35)$ & $0.54(0.33)$ \\
\hline
\end{tabular}




\section{Table 9}

This table report results of the Chow test for structural change in parameters before and after 1997 financial crisis (exchange rate level data). Regressors include exchange rate level variables (i.e., EXRATE_N and EXRATE_REAL), GS, KOSPI, EXPORT, IMPORT, OPENNESS, STRIKE_RATIO, WAGE_DIFF, TAX_DIFF, CGDP, BIT and interactive variables between regressors and group dummy ( $\left.D_{\text {crisis }}\right)$.

\begin{tabular}{lll}
\hline Exchange Rate & $\begin{array}{l}\text { Real FDI as Dependent } \\
\text { Variable }\end{array}$ & $\begin{array}{l}\text { FDI share in GDP_KOREA as } \\
\text { Dependent Variable }\end{array}$ \\
\hline Nominal Exchange & $\chi^{2}(13)=48.35$ & $\chi^{2}(13)=102.63$ \\
Rate & $p>\chi^{2}=0.000$ & $p>\chi^{2}=0.000$ \\
& $\chi^{2}(13)=42.06$ & $\chi^{2}(13)=102.52$ \\
Real Exchange & $p>\chi^{2}=0.000$ & $p>\chi^{2}=0.000$ \\
Rate &
\end{tabular}




\section{Table 10}

This table reports results of estimation of the two group model using exchange rate level (dependent variable is FDI_Real). $R^{2}$ denotes within-group (overall) coefficient of determination. P-value under the coefficient is based on the heteroskedastic and autocorrelation efficient standard errors. Constants are not shown.

\begin{tabular}{|c|c|c|c|c|}
\hline Variable & $\begin{array}{l}\text { Before } \\
\text { Crisis }\end{array}$ & $\begin{array}{l}\text { After } \\
\text { Crisis }\end{array}$ & $\begin{array}{l}\text { Before } \\
\text { Crisis }\end{array}$ & $\begin{array}{l}\text { After } \\
\text { Crisis }\end{array}$ \\
\hline \multirow[t]{2}{*}{ EXRATE_N } & 0.045 & -0.038 & & \\
\hline & 0.8367 & 0.8078 & & \\
\hline \multirow[t]{2}{*}{ EXRATE_N^2 } & 0.116 & -0.025 & & \\
\hline & 0.4117 & 0.0691 & & \\
\hline \multirow[t]{2}{*}{ EXRATE_REAL } & & & 0.06 & -0.08 \\
\hline & & & 0.7465 & 0.6634 \\
\hline \multirow[t]{2}{*}{ EXRATE_REAL $\wedge 2$} & & & 0.081 & -0.028 \\
\hline & & & 0.5055 & 0.0846 \\
\hline \multirow[t]{2}{*}{ EXPORT } & -2.164 & 0.152 & -2.204 & 0.153 \\
\hline & 0.0123 & 0.0824 & 0.01 & 0.0767 \\
\hline \multirow[t]{2}{*}{ IMPORT } & 0.044 & -0.444 & 0.071 & -0.443 \\
\hline & 0.9646 & 0.3324 & 0.9429 & 0.3282 \\
\hline \multirow[t]{2}{*}{ OPENNESS } & -0.004 & -0.055 & -0.015 & -0.048 \\
\hline & 0.7798 & 0.6342 & 0.4224 & 0.6695 \\
\hline \multirow[t]{2}{*}{ STRIKE_RATIO } & 0.001 & 0.345 & 0.001 & 0.345 \\
\hline & 0.3009 & 0 & 0.1958 & 0 \\
\hline \multirow[t]{2}{*}{ TAX_DIFF } & -0.005 & -0.015 & -0.005 & -0.015 \\
\hline & 0.2275 & 0.5391 & 0.2251 & 0.534 \\
\hline \multirow[t]{2}{*}{ WAGE_DIFF } & -0.018 & 0.035 & -0.018 & 0.038 \\
\hline & 0.55 & 0.6991 & 0.5583 & 0.6748 \\
\hline \multirow[t]{2}{*}{ IP } & 0.154 & -0.459 & & \\
\hline & 0.0771 & 0.095 & & \\
\hline \multirow[t]{2}{*}{ BIT } & -0.033 & 0.229 & -0.095 & -0.244 \\
\hline & 0.4466 & 0.1561 & 0.2153 & 0.0165 \\
\hline \multirow[t]{2}{*}{ GS } & & & 0.276 & 0.376 \\
\hline & & & 0.0786 & 0.0052 \\
\hline Time Effects & Yes & Yes & Yes & Yes \\
\hline $\mathrm{N}$ & 100 & 48 & 100 & 48 \\
\hline$R^{2}$ & $0.34(0.33)$ & $0.47(0.47)$ & $0.34(0.33)$ & $0.47(0.47)$ \\
\hline
\end{tabular}


Table 11

This table reports results of estimation of the crisis dummy variable model using exchange rate level (dependent variable is FDI_REAL). $R^{2}$ denotes within-group (overall) coefficient of determination. Pvalue under the coefficient is based on the heteroskedastic and autocorrelation efficient standard errors. Constants are not shown.

\begin{tabular}{|c|c|c|c|c|}
\hline Variable & $\begin{array}{c}\text { Model1:Long } \\
\text { Run Effect }\end{array}$ & $\begin{array}{c}\text { Model2:Short Run } \\
\text { Effect } \\
\end{array}$ & $\begin{array}{c}\text { Model1':Long } \\
\text { Run Effect }\end{array}$ & $\begin{array}{c}\text { Model2':Short } \\
\text { Run Effect }\end{array}$ \\
\hline \multirow[t]{2}{*}{ EXRATE_N } & 0.962 & 2.049 & & \\
\hline & 0.4737 & 0.0505 & & \\
\hline \multirow[t]{2}{*}{ CRISIS97_06 } & 9.029 & & 9.109 & \\
\hline & 0.0861 & & 0.1016 & \\
\hline \multirow[t]{2}{*}{ CRISIS97_06*EXRATE_N } & 0.421 & & & \\
\hline & 0.8858 & & & \\
\hline \multirow[t]{2}{*}{ CRISIS97_98 } & & -8.933 & & -8.886 \\
\hline & & 0.0301 & & 0.0315 \\
\hline \multirow[t]{2}{*}{ CRISIS97_98*EXRATE_N } & & -1.383 & & \\
\hline & & 0.7629 & & \\
\hline \multirow[t]{2}{*}{ EXRATE_REAL } & & & 0.465 & 1.741 \\
\hline & & & 0.6189 & 0.0382 \\
\hline \multirow[t]{2}{*}{ CRISIS97_06 } & & & 1.093 & \\
\hline & & & 0.7504 & \\
\hline \multirow[t]{2}{*}{ CRISIS97_98*EXRATE_REAL } & & & & -1.016 \\
\hline & & & & 0.8451 \\
\hline \multirow[t]{2}{*}{ EXPORT } & -2.72 & -5.22 & -2.823 & -5.469 \\
\hline & 0.7075 & 0.5259 & 0.6942 & 0.5091 \\
\hline \multirow[t]{2}{*}{ IMPORT } & 3.949 & 6.845 & 4.024 & 6.891 \\
\hline & 0.3093 & 0.1394 & 0.2977 & 0.1414 \\
\hline \multirow[t]{2}{*}{ OPENNESS } & -0.024 & -0.098 & -0.024 & -0.094 \\
\hline & 0.5906 & 0.0296 & 0.5798 & 0.0324 \\
\hline \multirow[t]{2}{*}{ STRIKE_RATIO } & -0.01 & -0.009 & -0.01 & -0.01 \\
\hline & 0.1413 & 0.2031 & 0.1107 & 0.1769 \\
\hline \multirow[t]{2}{*}{ CGDP } & 4.171 & 0.942 & 4.043 & 0.533 \\
\hline & 0.6097 & 0.9093 & 0.6107 & 0.945 \\
\hline \multirow[t]{2}{*}{ TAX_DIFF } & 0.249 & 0.261 & 0.246 & 0.257 \\
\hline & 0.1384 & 0.1236 & 0.1395 & 0.1269 \\
\hline \multirow[t]{2}{*}{ WAGE_DIFF } & 0.275 & 0.574 & 0.275 & 0.534 \\
\hline & 0.4573 & 0.1654 & 0.4398 & 0.1872 \\
\hline \multirow[t]{2}{*}{ KOSPI } & 4.998 & 7.194 & 4.864 & 6.973 \\
\hline & 0.0226 & 0.0093 & 0.0256 & 0.0109 \\
\hline \multirow[t]{2}{*}{ GS } & 2.979 & 5.614 & 2.926 & 5.393 \\
\hline & 0.0874 & 0.0048 & 0.0839 & 0.0068 \\
\hline \multirow[t]{2}{*}{ BIT } & 0.196 & 1.075 & 0.195 & 1.104 \\
\hline & 0.6036 & 0.0145 & 0.5931 & 0.0143 \\
\hline $\mathrm{N}$ & 152 & 152 & 152 & 152 \\
\hline$R^{2}$ & $0.31(0.21)$ & $0.31(0.20)$ & $0.31(0.21)$ & $0.31(0.20)$ \\
\hline
\end{tabular}

